BISMA

(Bisnis dan Manajemen)
Volume 10, Nomor 1, Oktober 2017, 26-46

ISSN 2549-7790 (Online)

ISSN 1979-7192 (Print)

https://journal.unesa.ac.id/index.php/bisma/index

\title{
Pengaruh Entrepreneurship Education terhadap Entrepreneurial Intention melalui Entrepreneurial Motivation sebagai Mediasi pada Mahasiswa Perguruan Tinggi Swasta di Surabaya
}

\author{
Ratih Indriyani \\ Universitas Kristen Petra \\ Email korespondensi: ranytaa@ petra.ac.id
}

\begin{abstract}
Entrepreneurship education has an important role throughout all education level, especially in the college, which its purpose to create a young generation of entrepreneur in the future.The purpose of this study were to analyze the influence of Entrepreneurship Education on Entrepreneurial Intention, the influence of Entrepreneurship Education on Entrepreneurial Motivation, and the influence of Entrepreneurial Intention toward Entrepreneurial Motivation. This study also investigates the mediating role of Entrepreneurial Motivation, related to entrepreneurship education and entrepreneurial intentions. The data analysis technique of this research was SEM, using smart software PLS (Partial Least Square). This study conducted on 150 private university students in Surabaya. The sampling method used in this research was non probability sampling with consecutive sampling method. The results showed that entrepreneurship education significantly influenced entrepreneurial intention with T-Statistic 2,020602, while entrepreneurship education had significant influence on entrepreneurial motivation with $T$ statistic 3,972756. The other results showed that entrepreneurial motivation had significant influence on entrepreneurial intention with T-statistic 3,651692. The results of the study showed that entrepreneurial motivation was not able to mediate the influence of entrepreneurship education on entrepreneurial intention.
\end{abstract}

Keywords: Entrepreneurship Education ; Entrepreneurial Intention;Entrepreneurial Motivation

Received: 3 Agustus 2017

Reviewed: 10 Oktober 2017

Accepted: 30 Oktober 2017

Published: 31 Oktober 2017

\section{PENDAhUluan}

Kondisi lapangan kerja di Indonesia diwarnai dengan prosentase pengangguran yang memiliki jumlah besar justru pada sumber daya manusia yang terdidik. Hardjanti (2012) mengungkapkan bahwa berdasarkan Data BPS Agustus 2012, jumlah penduduk Indonesia yang bekerja sebanyak 110,8 juta orang didominasi lulusan pendidikan Sekolah Dasar yakni sebesar 53,88 juta atau $48,63 \%$. Sementara itu, lulusan SMP sebanyak 20,22 juta atau 18,25\% dan lulusan universitas yang bekerja hanya sekitar 6,98 juta orang atau $6,30 \%$ serta lulusan pendidikan Diploma hanya mencapai 2,97 juta orang atau 2,68\%. Realita tersebut 
didukung dengan laporan dari ILO (2015) yang menjabarkan jumlah penganggur terbuka berdasarkan pendidikan tertinggi. Secara rinci terlihat dari tabel 1 berikut.

Tabel 1. Jumlah Pengangguran Terbuka Berdasarkan Pendidikan Tertinggi

\begin{tabular}{|c|c|c|c|c|}
\hline \multirow{2}{*}{ Pendidikan terakhir } & \multicolumn{2}{|c|}{ Jumlah pengangguran terbuka } & \multicolumn{2}{|c|}{$\begin{array}{c}\text { Tingkat pengangguran } \\
\text { terbuka }\end{array}$} \\
\hline & $15-24$ & $25+$ & $15-24$ & $25+$ \\
\hline Tidak bersekolah & 23.601 & 100.702 & $13,5 \%$ & $2,1 \%$ \\
\hline Tidak tamat SD & 217.953 & 385.241 & $18,3 \%$ & $2,2 \%$ \\
\hline SD & 608.794 & 711.598 & $16,6 \%$ & $2,4 \%$ \\
\hline SLTP & 819.091 & 831.296 & $14,8 \%$ & $4,7 \%$ \\
\hline SLTA & 1.032 .599 & 729.812 & $20,2 \%$ & $4,4 \%$ \\
\hline SMK & 842.909 & 331.457 & $19,9 \%$ & $3,8 \%$ \\
\hline Diploma I/II/III & 143.517 & 110.795 & $21,5 \%$ & $4,1 \%$ \\
\hline Universitas & 272.419 & 292.983 & $25,4 \%$ & $3,1 \%$ \\
\hline Total & 3.960 .883 & 3.493 .884 & $18,3 \%$ & $3,3 \%$ \\
\hline
\end{tabular}

Sumber: BPS (2015) Keadaan Angkatan Kerja: Februari 2015

Berdasarkan data laporan di atas, terlihat bahwa masyarakat Indonesia dengan lulusan dari universitas memiliki angkat pengangguran yang lebih tinggi dibandingkan dengan lainnya. Fenomena ini perlu menjadi perhatian khusus bagi pemerintah maupun instansi pendidikan. Salah satu upaya yang penting untuk dilakukan dalam mengatasi permasalahan tersebut adalah dengan melebarkan sayap wirausaha. Adanya wirausaha dapat membantu negara dalam mengejar pertumbuhan ekonomi agar angka kemiskinan menurun dan kesejahteraan meningkat sesuai dengan target penurunan gini ratio pada 2019 dari 0,14\% menjadi 0,36\% (Sabandar, 2016).

Pentingnya upaya mengembangkan wirausaha di Indonesia tidak berbanding lurus dengan besarnya minat berwirausaha masyarakat. Rendahnya minat berwirausaha diungkapkan oleh Himawan (2016), bahwa saat ini Indonesia baru memiliki $1,5 \%$ pengusaha dari 252.000 .000 penduduk. Indonesia masih memerlukan sekitar 1,7juta pengusaha untuk mencapai target 2\%. Angka tersebut menunjukkan bahwa posisi Indonesia kalah dengan beberapa negara ASEAN, yakni Singapura tercatat sebanyak 7\%, Malaysia 5\%, Thailand 4,5\%, dan Vietnam $3,3 \%$ jumlah pengusaha.

Menyikapi hal tersebut, maka Kemenperin melakukan beberapa upaya untuk mendorong tumbuhnya wirausaha baru diantaranya adalah: (1) menciptakan iklim usaha yang kondusif melalui pembuatan regulasi; (2) melakukan pemberian stimulasi melalui instrumen moneter maupun fiskal; (3) memberikan pelayanan publik yang prima; (4) melaksanakan prinsip clean government; dan (5) menyediakan fasilitas infrastruktur yang cukup baik (Julianto, 2016). Berdasarkan fenomena tersebut, maka penting adanya pendidikan kewirausahaan di seluruh 
jenjang pendidikan, utamanya di Perguruan Tinggi karena mahasiswa merupakan agent of change.

Terlebih lagi bagi mahasiswa Surabaya, yang mana Surabaya merupakan kota kedua terbesar di Indonesia setelah Jakarta (kompasiana.com). Nanda (2013) juga mengungkapkan bahwa Surabaya dengan luas daratan $333.063 \mathrm{~km}^{2}$ dan memiliki jumlah penduduk mencapai 3 juta jiwa lebih. Hal inilah yang menyebabkan Surabaya menjadi pusat bisnis di kawasan Jawa Timur. Dengan adanya keadaan ini, maka penting pemberian bekal kepada mahasiswa yang ada di Surabaya agar mampu menciptakan wirausaha dan membuka lapangan pekerjaan baru sehingga mampu mengurangi pengangguran di Indonesia, khususnya Surabaya dan Jawa Timur.

Adanya pendidikan kewirausahaan ini nantinya diharapkan mampu memberikan motivasi kepada mahasiswa untuk menciptakan wirausaha. Sehingga dengan adanya motivasi tersebut mampu melahirkan niat untuk memilih wirausaha sebagai karirnya. Untuk itu, dalam penelitian ini ingin melihat "Pengaruh Entrepreneurship Education Terhadap Entrepreneurial Intention Melalui Entrepreneurial Motivation Sebagai Mediasi Pada Mahasiswa Perguruan Tinggi Swasta Di Surabaya".

Tujuan dari penelitian ini diantaranya adalah untuk menganalisa pengaruh entrepreneurship education Terhadap entrepreneurial intention, untuk menganalisa pengaruh entrepreneurship education Terhadap entrepreneurial motivation, untuk menganalisa pengaruh entrepreneurial intention Terhadap entrepreneurial motivation, dan untuk menganalisa seberapa kuat entrepreneurial motivation dalam memediasi entrepreneurial education Terhadap entrepreneurial intention

\section{Entrepreneurship Education}

Pendidikan kewirausahaan merupakan segala aktivitas yang bertujuan untuk menanamkan pemikiran atau mindset mengenai kewirausahaan, menumbuhkan niat, sikap dan kompetensi seseorang dalam mengembangkan potensi dirinya dengan mewujudkan perilaku kreatif dan inovatif. Pendidikan kewirausahaan memiliki manfaat dari prinsip-prinsip empiris dan konseptual yang mana telah ditetapkan dengan basis kewirausahaan itu sendiri (Morris \& Liguori, 2016:87). Definisi tersebut menggambarkan bahwa dengan adanya pendidikan kewirausahaan maka akan dapat menumbuhkan keinginan peserta didik untuk melakukan wirausaha. Hal ini sebagaimana yang diungkapkan oleh Lekoko, Rankhumise, \& Ras (2012) bahwa pendidikan kewirausahaan ini memiliki posisi yang sangat penting untuk mengembangkan keterampilan kewirausahaan, sikap dan perilaku sebagai pembentuk dasar bagi pertumbuhan ekonomi suatu negara. Adapun tujuan dari pendidikan kewirausahaan ini diantaranya adalah untuk: (1) meningkatkan kesadaran dan pemahaman dalam kewirausahaan, 
meningkatkan kesadaran bahwa kewirausahaan sebagai jenjang karir. Untuk itu, sebagai lembaga pendidikan utamanya universitas memiliki peran penting dalam menumbuhkan dan memberikan motivasi terkait manfaat dan keuntungan dalam berwirausaha.

Pentingnya pendidikan kewirausahaan juga didasari dari beberapa hal penting, diantaranya adalah sebagai berikut: dapat memberikan perasaan kemandirian dan kepercayaan diri kepada seorang individu dan memungkinkan pengakuan pilihan karir alternatif, Melalui pendidikan kewirausahaan , siswa diharapkan mampu memperluas cakrawala individu dengan memungkinkannya untuk lebih memahami peluang usaha serta memberikan pengetahuan bahwa pengetahuan tersebut akan digunakan dalam mengembangkan peluang bisnis baru (Dogan, 2015).

\section{Entrepreneurial Intention}

Niat kewirausahaan (entrepreneurial intention) merupakan sebuah keyakinan bahwa karir kewirausahaan merupakan alternatif yang baik untuk dirinya, dengan memilih jalan tersebut akan berorientasi pada aksi menuju tujuan penciptaan usaha (Kyro, 2015:232). Mat, Maat, \& Mohd (2015) mengungkapkan bahwa niat kewirausahaan dapat dipengaruhi oleh faktor kepribadian. Kaktor kepribadian yang berperan di dalamnya meliputi tiga komponen yakni need for achievement, locus of control, dan self-efficacy. Need for achievement merupakan sikap seseorang yang memiliki kebutuhan untuk berprestasi. Apabila seseorang memiliki keinginan yang kuat untuk berprestasi maka dia akan berusaha kuat dan berani mengambil risiko dalam mencapai tujuan serta target yang ditetapkan. Locus of control merupakan konsep yang mengacu pada keyakinan bahwa seseorang dapat atau tidak dapat mengendalikan dirinya. Hal ini berhubungan dengan kemampuan seseorang untuk melihat peluang yang akan datang. Selfefficacy merupakan harapan yang dimiliki oleh seseorang atas berbagai usaha pribadinya yang mampu menguasai situasi dan menciptakan berbagai hasil yang diinginkan. Self-efficacy ini dipengaruhi oleh faktor-faktor kontekstual seperti pendidikan dan pengalaman sebelumnya.

Selain dari pengaruh kepribadian tersebut, pengaruh dari lingkungan juga akan berdampak pada niat seseorang untuk melakukan wirausaha. Pada penelitian yang dilakukan oleh Khuong \& An (2016) mengungkapkan bahwa untuk melihat niat kewirausahaan pada seseorang tidak hanya dari kepribadian akan tetapi dari lingkungan eksternal. Hasil yang ditemukan dalam penelitian tersebut adalah pengalaman kewirausahaan, lingkungan eksternal dan kelayakan merupakan variabel yang secara signifikan mempengaruhi persepsi positif terhadap kewirausahaan dan secara tidak langsung berpengaruh terhadap niat kewirausahaan. Sementara itu, sifat pribadi secara signifikan mempengaruhi 
persepsi negatif terhadap kewirausahaan dan secara langsung memiliki pengaruh terhadap niat kewirausahaan.

\section{Entrepreneurial Motivation}

Motivasi berwirausaha (Entrepreneurial Motivation) diartikan sebagai proses yang membawa seseorang untuk mengadopsi keinginan dari suatu tindakan. Hal ini bermanfaat untuk mengintensifkan seseorang dalam melakukan kerja keras guna mencapai tujuan dan kepuasan diri (Kumar, Poornima, Abraham, \& Jayashree, 2003:12). Adapun faktor yang mempengaruhi motivasi dalam hal ini dapat dikatakan sebagai faktor penarik dan faktor pendorong. Faktor penarik yang dimaksudkan yaitu dengan melakukan wirausaha akan mampu mengendalikan waktunya sendiri untuk bekerja. Sementara itu, faktor pendorong yang dimaksudkan yaitu menghindari pimpinan yang kasar. Kendati demikian, banyak penelitian yang menyebutkan bahwa motivasi seseorang untuk melakukan wirausaha adalah adanya faktor penarik (Fereidouni, Masron, Nikbin, \& Amiri, 2010).

Hal ini sebagaimana yang diungkapkan oleh Sloka, Kantane, Avotins, \& Jermolajeva (2014) bahwa motivasi terkuat seseorang melakukan wirausaha diantaranya adalah meningkatkan pendapatan dan memilih untuk bebas dari tekanan. Adapun faktor yang dianggap kurang penting dari motivasi seseorang dalam melakukan wirausaha adalah menyediakan lapangan pekerjaan, dan mendapatkan pengakuan dari publik. Mitchell (2003) juga mengungkapkan hal serupa bahwa faktor yang mendominasi motivasi diantaranya adalah kebanggaan diri individu, berkontribusi untuk kesejahteraan kelompok, adanya pengakuan dari orang lain, insentif material, dan fleksibilitas kerja.

Stephan, Hart, \& Drews (2015) menjabarkan bahwa motivasi dalam berwirausaha dapat digolongkan menjadi beberapa dimensi, diantaranya adalah sebagai berikut: (1) prestasi, tantangan dan belajar: hal ini berarti seseorang melakukan wirausaha dengan motivasi untuk belajar tantangan dan mengembangkan ilmu yang didapatkan melalui penciptaan bisnis baru, (2) kemerdekaan dan ekonomi: hal ini berarti bahwa seseorang melakukan wirausaha dengan motivasi mencari kebebasan, mampu membuat keputusan secara independen dan fleksibel, (3) jaminan pendapatan dan kesuksesan finansial: hal ini berarti seseorang melakukan wirausaha dengan motivasi akan mendapatkan pengembalian uang, dan (4) pengakuan dan status: hal ini berarti seseorang melakukan wirausaha dengan motivasi untuk mendapatkan pengakuan dan rasa hormat dari teman-teman, keluarga, serta masyarakat. 


\section{Pengembangan Hipotesis}

\section{Pengaruh Entrepreneurship Education terhadap Entrepreneurial Intention}

Pendidikan kewirausahaan memberikan wawasan tentang manfaat serta pentingnya kewirausahaan. Dengan demikian, pendidikan kewirausahaan berkorelasi niat kewirausahaan karena didasarkan pada tiga alasan, diantaranya adalah sebagai berikut: (1) pendidikan kewirausahaan membantu siswa untuk belajar dan mengidentifikasi peluang bisnis baru; (2) pendidikan dapat mensosialisasikan individu ke dalam karir kewirausahaan; (3) pendidikan kewirausahaan memberikan pengetahuan tentang cara memulai usaha bisnis yang baik (Hussain \& Norashidah, 2015).

Untuk itu, Gerba (2012) dalam penelitiannya menunjukkan bahwa pendidikan kewirausahaan memiliki pengaruh terhadap niat kewirausahaan. Hal ini terlihat dari hasil penelitian yang memperlihatkan bahwa siswa yang telah menjalani pendidikan kewirausahaan cenderung memiliki niat kewirausahaan yang lebih baik dibandingkan siswa yang mengambil kursus kewirausahaan. Kendati demikian, Bae, Qian, Miao, \& Fiet (2014) dalam penelitiannya menunjukkan bahwa hasilnya mengungkapkan bahwa pendidikan kewirausahaan dan niat kewirausahaan memiliki hubungan yang tidak signifikan. Sementara itu, pendidikan kewirausahaan memiliki pengaruh terhadap niat perusahaan dengan dimoderatori oleh beberapa variabel, diantaranya adalah evaluator program dan nilai-nilai budaya. Hal tersebut didukung dengan penelitian yang dilakukan oleh Oosterbeek, Praag, \& Ijsselstein (2010) bahwa pendidikan kewirausahaan tidak memiliki pengaruh yang signifikan terhadap niat kewirausahaan. Penelitian tersebut mengemukakan bahwa kondidi ini disebabkan karena niat kewirausahaan tidak serta merta dimiliki oleh setiap individu, kecuali jika individu tersebut memiliki niat dari dalam diri untuk melakukan wirausaha.

Berdasarkan beberapa penelitian terdahulu di atas, maka hipotesis yang diajukan dalam penelitian ini adalah:

H1 : Entrepreneurship Education memiliki pengaruh terhadap Entrepreneurial Intention

\section{Pengaruh Entrepreneurship Education terhadap Entrepreneurial Motivation}

Adanya pendidikan kewirausahaan mampu memberikan motivasi terhadap siswa untuk melakukan kegiatan kewirausahaan. Hal ini sebagaimana yang diungkapkan oleh Lekoko, Rankhumise, \& Ras (2012) bahwa tujuan dari pendidikan kewirausahaan diantaranya adalah untuk: (1) meningkatkan kesadaran dan pemahaman dalam kewirausahaan, (2) meningkatkan kesadaran bahwa kewirausahaan sebagai jenjang karir.

Hasil penelitian dari Oosterbeek, Praag, \& Ijsselstein (2010) mengungkapkan bahwa pendidikan kewirausahaan memiliki pengaruh terhadap motivasi kewirausahaan. Sebab dalam pendidikan kewirausahaan diterapkan 
berbagai aktivitas yang membangkitkan motivasi siswa dalam berwirausaha. Kendati demikian, Somby \& Johansen (2016) dalam penelitiannya mengungkapkan bahwa pendidikan kewirausahaan tidak memiliki pengaruh yang signifikan terhadap motivasi berwirausaha. Adapun yang memiliki pengaruh terhadap motivasi berwirausaha adalah partisipasi dari siswa itu sendiri.

Berdasarkan hasil yang didapatkan antara dua penelitian di atas, maka hipotesis yang diajukan dalam penelitian ini adalah:

H2 : Entrepreneurship Education memiliki pengaruh terhadap Entrepreneurial Motivation

\section{Pengaruh Entrepreneurship Motivation terhadap Entrepreneurship Intention}

Motivasi berwirausaha diartikan sebagai rasa yang muncul dari dalam diri seorang individu sehingga melahirkan keinginan untuk melakukan suatu aktivitas. Adanya motivasi yang timbul dari dalam diri tersebut secara tidak langsung juga menumbuhkan niat seseorang untuk berwirausaha. Hal ini sebagaimana penelitian yang dilakukan oleh Kim-Soon, Ahmad, \& Ibrahim (2014), yang mana dari hasil penelitiannya mengungkapkan bahwa kekuatan motivasi siswa dalam memilih kewirausahaan sebagai pilihan karir memiliki hubungan yang erat dengan niat kewirausahaan. Adapun faktor-faktor motivasi kewirausahaan yang mempengaruhi niat berwirausaha diantaranya meliputi kontrol perilaku, norma subyektif, dan sikap terhadap kewirausahaan.

Berdasarkan beberapa penelitian terdahulu di atas, maka hipotesis yang diajukan dalam penelitian ini adalah:

H3 : Entrepreneurship Motivation memiliki pengaruh terhadap Entrepreneurship Intention

\section{Pengaruh Entrepreneurship Education terhadap Entrepreneurial Intention melalui Entrepreneurial Motivation}

Pendidikan kewirausahaan dapat menumbuhkan motivasi siswa dalam berwirausaha. Dengan adanya motivasi dalam berwirausaha tersebut akan melahirkan niat siswa dalam melakukan wirausaha tersebut. Hal ini sebagaimana penelitian yang dilakukan oleh Solesvik (2013) yakni mengungkapkan bahwa seorang individu yang berpartisipasi dalam program perusahaan cenderung memiliki motivasi kewirausahan yang tinggi dan memiliki niat yang lebih untuk menjadi pengusaha. Bukti empiris menunjukkan bahwa sikap memediasi hubungan antara motivasi kewirausahaan dan niat kewirausahaan.

Berdasarkan beberapa penelitian terdahulu di atas, maka hipotesis yang diajukan dalam penelitian ini adalah:

H4 : Entrepreneurial Motivation mampu memediasi Entrepreneurship Education terhadap Entrepreneurial Intention 


\section{METODE PENELITIAN}

\section{Jenis Penelitian}

Penelitian ini menggunakan pendekatan kuantitatif. Sugiyono (2012:55) mengemukakan bahwa pendekatan kuantitatif yaitu pendekatan penelitian yang menggunakan data berupa angka-angka hasil jawaban survey yang disebarkan ke sampel penelitian dan dianalisis menggunakan teknik analisis statistik.

\section{Definisi Operasional Variabel \\ Entrepreneurship Education}

Adapun indikator yang digunakan untuk mengukur pendidikan kewirausahaan di antaranya adalah sebagai berikut (Lekoko, Rankhumise, \& Ras, 2012). (1) Memberikan kesempatan bagi siswa untuk belajar untuk memiliki orientasi kewirausahaan. Kreiser \& Davis (2010) mengungkapkan bahwa untuk mengukur entrepreneurial orientation meliputi tiga hal diantaranya adalah pengambilan risiko, inovatif, dan proaktif. Adapun penjelasannya adalah sebagai berikut. (a) Pengambilan risiko berhubungan dengan sejauh mana seseorang bersedia untuk membuat sebuah komitmen dan memiliki kekuatan yang besar apabila mengalami kegagalan. Adapun beberapa hal yang berkaitan dengan risk taking yaitu pendidikan kewirausahaan yang mengajarkan mengenai berani mengambil risiko dan pendidikan kewirausahaan mendorong untuk mengembangkan ide baru (b) Bersifat Inovatif, berhubungan dengan adanya ideide baru yang muncul dari proses kreatif, kondisi ini berkaitan dengan pendidikan kewirausahaan mendorong untuk mempelajari kemungkinan pengembangan metode baru dan pendidikan kewirausahaan mengajarkan cara beradaptasi dengan perubahan kondisi lingkungan (c) Proaktif berhubungan dengan mencari kesempatan ke depan untuk mengembangkan produk yang bertujuan agar mampu bersaing dalam menghadapi kompetitifnya persaingan. Hal ini berkaitan dengan pendidikan kewirausahaan mengajarkan siswa untuk merespon yang cepat terhadap perubahan lingkungan usaha dan pendidikan kewirausahaan mengajarkan siswa untuk melihat berbagai peluang dalam usaha (2) Meningkatkan self-efficacy mahasiswa. Hal ini berkaitan dengan persepsi diri seorang individu yang merasa bahwa dirinya mampu menjalankan kewirausahaan, yang mana dalam hal ini dapat diukur dengan indikator kepercayaan bahwa kelak mampu menjadi wirausaha, keyakinan bahwa kelak mampu menjalankan bisnis sendiri, dan keyakinan mampu memberikan hasil yang maksimal.

\section{Entrepreneurial Intention}

Niat kewirausahaan dapat diukur dengan beberapa indikator sebagai berikut (Tsordia \& Papadimitriou, 2015). (1) Kesiapan dalam melakukan apa saja untuk menjadi pengusaha. (2) Tujuan hidup secara profesional adalah untuk menjadi seorang pengusaha. (3) Berniat melakukan segala usaha untuk memulai dan 
menjalankan perusahaan saya sendiri. (4) Bertekad untuk membuat usaha bisnis di masa depan. (5) Telah berpikir dengan sangat serius untuk memulai sebuah perusahaan. (6) Berniat untuk memulai sebuah perusahaan dalam jangka waktu lima tahun setelah kelulusan dan menjadikan wirausaha sebagai pilihan karir

\section{Entrepreneurial Motivation}

Indikator yang digunakan untuk mengukur entrepreneurship motivation diantaranya adalah sebagai berikut (Venesaar, Kolbre, \& Piliste, 2006). (1) Ambition for freedom, indikator ini secara lebih rinci dapat diukur melalui beberapa turunan indikator yaitu berkeinginan lebih mandiri, berkeinginan memiliki usaha sendiri, berkeinginan untuk lebih dihormati, dan berkeinginan menjadi yang terdepan dalam menerapkan ide baru. (2) Self realization, indikator ini secara lebih rinci dapat diukur melalui beberapa turunan indicator, yaitu melakukan kegiatan kewirausahaan untuk mendapatkan posisi yang lebih baik di masyarakat, melakukan kegiatan kewirausahaan untuk merasakan tantangan, melakukan kegiatan kewirausahaan karena ingin memotivasi dan memimpin orang lain, melakukan kegiatan kewirausahaan karena ingin melanjutkan tradisi keluarga, dan melakukan kegiatan kewirausahaan karena ingin merealisasikan ide usaha.

\section{Pushing Factor}

Indikator ini secara lebih rinci dapat diukur melalui keinginan untuk mendapatkan pendapatan yang baik dan Keinginan bahwa apabila kelak tidak bekerja, memiliki pilihan untuk berwirausaha.

\section{Populasi dan Sampel}

Populasi dalam penelitian ini adalah mahasiswa Perguruan Tinggi Swasta di Surabaya. Sementara itu, pengambilan sampel dalam penelitian ini menggunakan teknik pengambilan sampel tidak acak (nonprobablity sampling) dengan metode consecutive sampling. Metode consecutive sampling adalah teknik pengambilan sampel tidak acak (nonprobability sampling) dengan membuat kriteria sampel penelitian. Kriteria sampel penelitian yang digunakan adalah mahasiswa yang mendapatkan mata kuliah kewirausahaan.

Pengambilan sampel pada analisis data dengan menggunakan Structural Equation Model (SEM) Partial Least Square tidak terlalu besar (Ghozali, 2008). Pendapat lain menyatakan bahwa pengambilan sampel pada populasi yang tidak diketahui dilakukan menggunakan beberapa pertimbangan tertentu dengan tertentu dengan ukuran sampel yang sesuai yaitu antara 100-200. Untuk itu, sampel yang digunakan dalam penelitian ini berjumla 150 responden. 


\section{Instrumen Penelitian}

Pengumpulan data diperoleh dari data primer berupa kuesioner tertutup. Penelitian ini menggunakan kuesioner sebagai instrumen pengumpul data. Tata bahasa dalam menyusun pertanyaan kuesioner dibuat dengan penyesuaian bahasa yang dipahami mahasiswa dengan tujuan agar mahasiswa mudah mengerti pertanyaan dalam kuesioner, sehingga diperoleh hasil jawaban yang valid. Kuesioner tidak mencantumkan identitas nama responden untuk menjaga kerahasiaan serta memberikan rasa nyaman kepada responden yang telah berpartisipasi memberikan jawaban. Kuesioner yang dipakai adalah pernyataan.

Penelitian ini menggunakan skala Likert yang terbagi menjadi 5 (lima) skala, yaitu: Sangat setuju (SS) diberi skor 5, Setuju (S) diberi skor 4, Ragu-ragu (R) diberi skor 3, Tidak setuju (TS) diberi skor 2, dan Sangat tidak setuju (STS) diberi skor 1

Dengan skala Likert, maka variabel yang akan diukur dijabarkan menjadi variabel indikator. Kemudian indikator tersebut dijadikan sebagai titik tolak untuk menyusun item-item instrumen yang dapat berupa pernyataan atau pertanyaan. Setelah skor diperoleh, rata-rata skor per responden dicari. Data responden secara individu didistribusikan berdasarkan kriteria tertentu, sehingga dapat dideskripsikan distribusi jawabannya.

\section{Teknik Analisis Data}

Pada penelitian ini teknik analisis data yang digunakan adalah analisis SEM dengan menggunakan sofware smart PLS (Partial Least Square). Adapun langkah-langkah analisis PLS menurut Ghozali (2008:22-26) adalah sebagai berikut. (1) Merancang model struktural atau inner model. Inner model yang kadang disebut juga (inner relation, structural model dan subtantive theory) adalah menggambarkan hubungan antar variabel laten berdasarkan pada substantive theory. (2) Merancang model pengukuran atau outer model. Outer model sering juga disebut (outer relation atau measurenment model) mendefinisikan bagaimana setiap blok indikator berhubungan dengan variabel laten. (3) Mengkontruksi diagram jalur. Dalam diagram alur, hubungan antar konstruk akan dinyatakan melalui anak panah. Anak panah yang lurus menunjukkan korelasi antar konstruk. Konstruk yang dibangun dalam diagram alur dapat dibedakan dalam dua kelompok, yaitu: (a) Konstruk Eksogen (Exogenous Constructs), yang dikenal juga sebagai source variables atau independent variables yang tidak diprediksi oleh variabel yang lain dalam model. Konstruk eksogen adalah konstruk yang dituju oleh garis dengan satu ujung panah. (b) Konstruk Endogen (Endogenous Construct), yang merupakan faktorfaktor yang diprediksi oleh satu atau beberapa konstruk. Konstruk endogen dapat memprediksi satu atau beberapa konstruk endogen lainnya, tapi konstruk eksogen hanya dapat berhubungan kausal dengan konstruk endogen. (4) Mengkonversi 
diagram jalur ke sistem persamaan. Persamaan yang dikembangkan dalam penelitian ini menunjukkan dua model yaitu persamaan pengukuran dan persamaan structural. (a) Persamaan model pengukuran atau Outer Model dengan indikator refleksif seperti yang terlihat pada persamaan 1 di bawah ini. (b) Persamaan model struktural (structural equation) atau Inner Model terlihat pada persamaan 2 di bawah ini.

$$
\begin{gathered}
=\beta_{0}+\beta_{\eta}+\Gamma \xi+\zeta \ldots \ldots \\
\eta_{\mathrm{j}}={ }_{\mathrm{i}} \beta_{\mathrm{ji}} \eta_{\mathrm{j}}+\mathrm{i} \gamma_{\mathrm{jb}} \xi_{\mathrm{b}}+\zeta_{\mathrm{j} . .}
\end{gathered}
$$

Keterangan:

$\mathrm{X}$ dan $\mathrm{Y}$ :Indikator atau manifest untuk variabel laten exogen dan endogen $\xi$ dan $\eta \quad$ : Exogen dan endogen

$\Lambda \mathrm{x}$ dan $\Lambda \mathrm{y}:$ Matrik loading yang menggambarkan koefisien regresi sederhana yang menghubungkan variabel laten dengan indikatornya

Ex dan عy : Kesalahan pengukuran atau noise

$\eta \quad:$ Variabel laten dependen

$\beta \mathrm{ji}$ dan $\gamma \mathrm{ji}$ : Koefisien jalur variabel laten endogen dengan exdogen

$\xi \quad:$ Vektor variabel laten exogen

$\zeta \quad$ : Vektor variabel residual (unexplained variance)

i dan $\mathrm{b} \quad$ : Range indeks

$\zeta_{\mathrm{j}} \quad$ :Inner residual variable

(4) Melakukan estimasi atau pendugaan parameter. Pendugaan parameter dilakukan untuk menghitung data variabel laten. Metode pendugaan parameter (estimasi) di dalam PLS adalah metode kuadrat terkecil (least square methods). Proses perhitungan dilakukan dengan cara iterasi, dimana iterasi akan berhenti jika telah tercapai kondisi convergent. Estimasi parameter yang didapat dengan PLS dapat dikategorikan menjadi tiga yaitu sebagai berikut (Ghozali, 2008:19). (a) Weight estimate yang digunakan untuk menciptakan skor variabel laten. (b) Path estimate (estimasi jalur) yang menghubungkan variabel laten dan antara variabel laten dan blok indikatornya (loading). (c) Means dan lokasi parameter (nilai konstanta regresi) untuk indikator dan variabel laten. (5) Goodness of fit. Dalam hal ini dibagi menjadi dua yaitu outer model dan inner model. (6) Evaluasi Model. Evaluasi Model ini dibagi menjadi dua yaitu outer model dan inner model. (a) Outer model terbagi menjadi dua yaitu reflektif dan formatif. Outer model reflektif dievaluasi dengan convergent dan discriminant validity dari indikatornya dan composite reability untuk block indikator. Sedangkan Outer model formatif dievaluasi berdasarkan substantive content yaitu dengan melihat tingkat signifikansi dari weight. (b) Inner model diukur dengan menggunakan beberapa kriteria yaitu $\mathrm{R}^{2}$ untuk variabel laten endogen, estimasi koefisien jalur merupakan nilai estimasi untuk hubungan jalur dalam model struktural yang diperoleh dengan 
prosedur bootstrapping dengan nilai yang harus signifikan, $\mathrm{f}^{2}$ untuk effect size, dan relevansi prediksi $\left(\mathrm{Q}^{2}\right)$. Apabila diperoleh nilai $\mathrm{Q}^{2}$ lebih dari nol hal tersebut memberikan bukti bahwa model memiliki predictive relevance namun apabila diperoleh nilai $\mathrm{Q}^{2}$ di bawah nol maka terbukti bahwa model tidak memiliki predictive relevance. Adapun asumsi yang digunakan dalam PLS adalah hubungan antar variabel laten dalam inner model dan aditif serta model struktural bersifat rekursif. (7) Pengujian Hipotesis. Pengujian hipotesis dalam penelitian ini dilakukan dengan melihat dari koefisien jalur yang ada dengan membandingkan antara nilai $\mathrm{t}$ statistik dan t tabel dengan dasar pengambilan keputusan sebagai berikut. (a) Jika nilai $T$ statistics lebih besar dari nilai $Z \alpha_{(0,05)}=1,645$ maka Ho ditolak dan $\mathrm{H}_{1}$ diterima, artinya berpengaruh signifikan. (b) Jika nilai $T$ statistics lebih kecil dari nilai $\mathrm{Z}_{(0,05)}=1,645$ maka Ho diterima dan Ha ditolak, artinya tidak berpengaruh secara signifikan.

\section{HASIL DAN PEMBAHASAN}

Diagram jalur yang dikembangkan pada penelitian ini dapat dilihat dalam gambar 1 sebagai berikut.

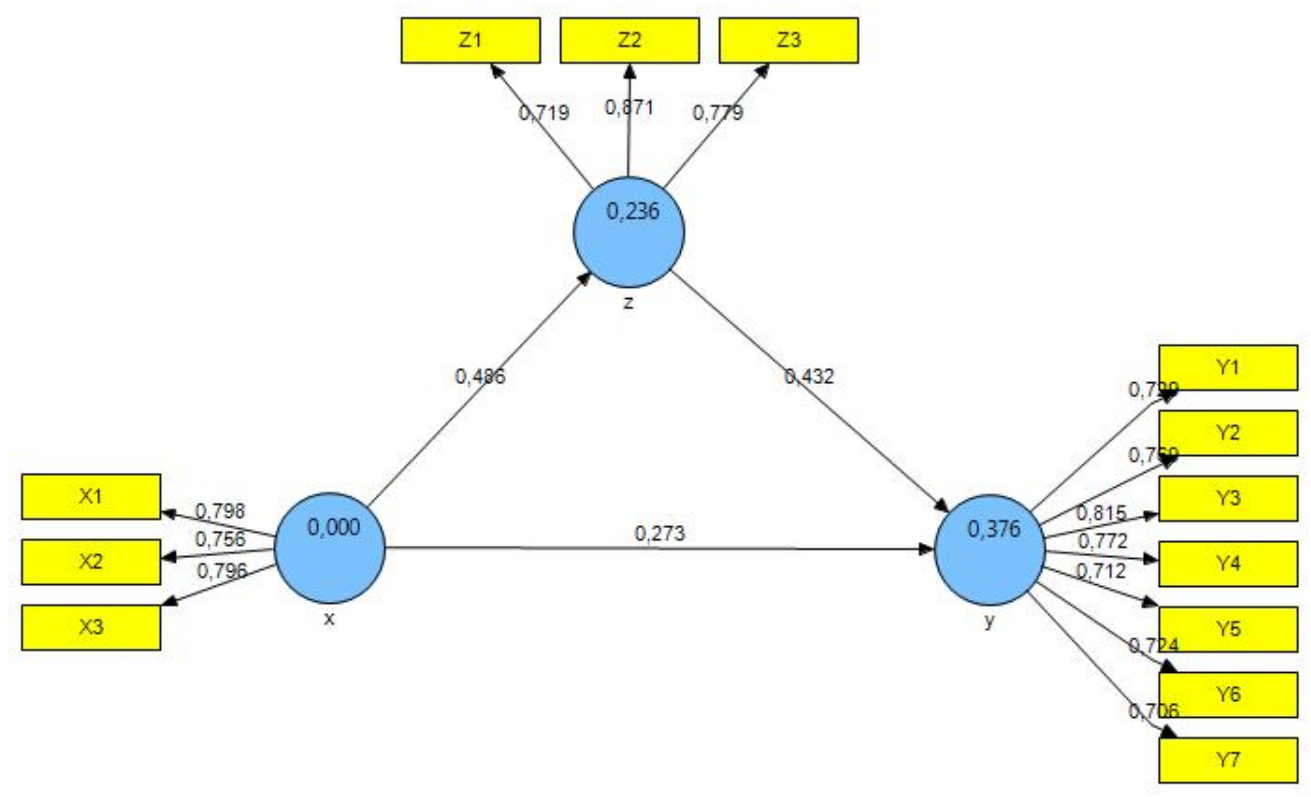

Gambar 1. Diagram Jalur PLS

\section{Evaluasi Validitas Konstruk}

Suatu instrumen dikatakan memenuhi pengujian validitas konvergen apabila memiliki loading factor di atas 0.6. Hasil pengujian validitas konvergen disajikan dalam tabel 2. Berdasarkan tabel 3 dapat diketahui bahwa semua indicator yang mengukur variabel entrepreneurship education, entrepreneurship intention, dan entrepreneurship motivation bernilai lebih besar dari 0.6. Dengan demikian indikator tersebut dinyatakan valid untuk mengukur variabelnya. 
Evaluasi validitas konstruk dilakukan dengan menghitung validitas konvergen dan validitas diskriminan. Validitas konvergen juga dapat diketahui melalui Average Variance Extracted (AVE) dan Communality. Suatu instrument dikatakan memenuhi pengujian validitas konvergen apabila memiliki Average Variance Extracted (AVE) dan Communality diatas 0.5. Hasil pengujian validitas konvergen disajikan dalam tabel 3 berikut.

Tabel 2. Validitas Konstruk

\begin{tabular}{cccccc}
\hline Variabel & Indikator & $\begin{array}{c}\text { Original } \\
\text { Sample (O) }\end{array}$ & $\begin{array}{c}\text { Standard } \\
\text { Error } \\
\text { (STERR) }\end{array}$ & $\begin{array}{c}\text { T Statistics } \\
(\text { |O/STERR })\end{array}$ & Keterangan \\
\hline \hline EE & $\mathrm{X} 1$ & 0,798428 & 0,06617 & 12,066258 & Valid \\
\hline EE & $\mathrm{X} 2$ & 0,756186 & 0,64288 & 11,7624 & Valid \\
\hline EE & $\mathrm{X} 3$ & 0,795665 & 0,042662 & 18,650591 & Valid \\
\hline EI & Y1 & 0,729021 & 0,048802 & 14,938463 & Valid \\
\hline EI & Y2 & 0,769321 & 0,051512 & 14,934876 & Valid \\
\hline EI & Y3 & 0,814513 & 0,041329 & 19,707911 & Valid \\
\hline EI & Y4 & 0,771858 & 0,048584 & 15,887113 & Valid \\
\hline EI & Y5 & 0,711808 & 0,054748 & 13,001536 & Valid \\
\hline EI & Y6 & 0,723606 & 0,052189 & 13,865213 & Valid \\
\hline EI & Y7 & 0,705769 & 0,061399 & 11,494811 & Valid \\
\hline EM & $\mathrm{Z} 1$ & 0,719136 & 0,077525 & 9,276162 & Valid \\
\hline EM & $\mathrm{Z} 2$ & 0,871172 & 0,029098 & 29,939368 & Valid \\
\hline EM & $\mathrm{Z} 3$ & 0,779274 & 0,055254 & 14,103434 & Valid \\
\hline
\end{tabular}

Tabel 3. Validitas Konvergen

\begin{tabular}{lcc}
\hline & AVE & Communality \\
\hline \hline Entrepreneurship Education & 0,614129 & 0,614129 \\
\hline Entrepreneurial Intention & 0,558701 & 0,558701 \\
\hline Entrepreneurial Motivation & 0,627788 & 0,627788 \\
\hline
\end{tabular}

Berdasarkan tabel 3 dapat diketahui bahwa semua variabel, yaitu entrepreneurship education, entrepreneurial intention, dan entrepreneurial motivation menghasilkan nilai Average Variance Extracted (AVE) dan Communality yang lebih besar dari 0.5 . Dengan demikian indikator tersebut dinyatakan valid untuk mengukur variabelnya.

Selanjutnya validitas diskriminan dihitung menggunakan cross correlation dengan kriteria bahwa apabila nilai loading factor dalam suatu variabel yang bersesuaian lebih besar dari nilai korelasi indikator pada variabel lainnya maka 
indikator tersebut dinyatakan valid dalam mengukur variabel yang bersesuaian. Hasil perhitungan cross correlation disajikan dalam tabel 4.

Berdasarkan pengukuran cross correlation pada tabel 4, dapat diketahui bahwa secara keseluruhan indikator-indikator dari variabel entrepreneurship education, entrepreneurial intention, dan entrepreneurial motivation menghasilkan loading factor yang lebih besar dibandingkan dengan cross correlation pada variabel lainnya. Dengan demikian dapat dinyatakan bahwa masing-masing indikator mampu mengukur variabel laten yang bersesuaian dengan indikatornya.

Tabel 4. Loading Factor

\begin{tabular}{cccc}
\hline & $\begin{array}{c}\text { Entrepreneurship } \\
\text { Education }\end{array}$ & Entrepreneurial Intention & $\begin{array}{c}\text { Entrepreneurial } \\
\text { Motivation }\end{array}$ \\
\hline \hline X1 & $\mathbf{0 , 7 9 8 4 2 8}$ & 0,338329 & 0,388015 \\
\hline X2 & $\mathbf{0 , 7 5 6 1 8 6}$ & 0,341941 & 0,291942 \\
\hline X3 & $\mathbf{0 , 7 9 5 6 6 5}$ & 0,441031 & 0,441312 \\
\hline Y1 & 0,412354 & $\mathbf{0 , 7 2 9 0 2 1}$ & 0,497351 \\
\hline Y2 & 0,29988 & $\mathbf{0 , 7 6 9 3 2 1}$ & 0,502499 \\
\hline Y3 & 0,400524 & $\mathbf{0 , 8 1 4 5 1 3}$ & 0,345613 \\
\hline Y4 & 0,326377 & $\mathbf{0 , 7 7 1 8 5 8}$ & 0,376525 \\
\hline Y5 & 0,400416 & $\mathbf{0 , 7 1 1 8 0 8}$ & 0,429854 \\
\hline Y6 & 0,349915 & $\mathbf{0 , 7 2 3 6 0 6}$ & 0,389958 \\
\hline Y7 & 0,322804 & $\mathbf{0 , 7 0 5 7 6 9}$ & 0,37185 \\
\hline Z1 & 0,354623 & 0,416393 & $\mathbf{0 , 7 1 9 1 3 6}$ \\
\hline Z2 & 0,484507 & 0,502664 & $\mathbf{0 , 8 7 1 1 7 2}$ \\
\hline Z3 & 0,288927 & 0,415048 & $\mathbf{0 , 7 7 9 2 7 4}$ \\
\hline
\end{tabular}

\section{Hasil Evaluasi Reliabilitas}

Hasil perhitungan composite reliability dan cronbach alpha dapat dilihat melalui ringkasan yang disajikan dalam tabel 5 berikut.

Tabel 5. Uji Reliabilitas

\begin{tabular}{lcc}
\hline & Composite Reliability & Cronbachs Alpha \\
\hline \hline Entrepreneurship Education & 0,826741 & 0,690752 \\
\hline Entrepreneurial Intention & 0,898382 & 0,868124 \\
\hline Entrepreneurial Motivation & 0,834119 & 0,702146 \\
\hline
\end{tabular}

Berdasarkan tabel 5 dapat diketahui bahwa nilai composite reliability pada variabel enterpreneurship education sebesar 0,826741, variabel enterpreneurial intention sebesar 0,898382, dan variabel enterpreneurial motivation sebesar 0,834119 . Hasil tersebut menunjukkan nilai composite reliability yang lebih besar 
dari 0,7. Dengan demikian, berdasarkan perhitungan composite reliability semua indikator dinyatakan reliabel dalam mengukur variabel latennya.

Selanjutnya nilai Cronbach's Alpha pada variabel enterpreneurship education sebesar 0,690752, variabel enterpreneurial intention sebesar 0,868124, dan variabel enterpreneurial motivation sebesar 0,702146. Hasil tersebut menunjukkan semua variabel menghasilkan nilai Cronbach's Alpha yang lebih besar dari 0.6. Dengan demikian, berdasarkan perhitungan Cronbach's Alpha semua indikator dinyatakan reliabel dalam mengukur variabel latennya.

\section{Goodness of Fit Model}

Goodness of fit Model digunakan untuk mengetahui besarnya kemampuan variabel endogen untuk menjelaskan keragaman variabel eksogen, atau dengan kata lain untuk mengetahui besarnya kontribusi variabel eksogen terhadap variabel endogen. Goodness of fit Model dalam analisis PLS dilakukan dengan menggunakan $Q$-Square predictive relevance $\left(Q^{2}\right)$.

Adapun hasil Goodness of fit Model yang telah diringkas dalam tabel 6 berikut.

Tabel 6. Goodness of fit Model

\begin{tabular}{lc}
\hline \multicolumn{1}{c}{ Variabel } & $\boldsymbol{R}^{2}$ \\
\hline \hline Entrepreneurship Intention & 0,376399 \\
\hline Entrepreneurial Motivation & 0,236355 \\
\hline $\mathrm{Q}^{2}=1-\left(1-\mathrm{R}_{1}{ }^{2}\right)\left(1-\mathrm{R}_{2}{ }^{2}\right) \rightarrow \mathrm{Q}^{2}=1-(1-0,376399)(1-0,236355)=$ \\
0.5237902144
\end{tabular}

Pengujian signifikansi digunakan untuk menguji ada tidaknya pengaruh variabel eksogen terhadap variabel endogen. Kriteria pengujian menyatakan bahwa apabila nilai T-statistics $\geq$ T-tabel (1.645) maka dinyatakan adanya pengaruh signifikan variabel eksogen terhadap variabel endogen. Hasil pengujian signifikansi dapat diketahui melalui tabel 7 berikut.

Tabel 7. Uji Hipotesis

\begin{tabular}{llcccc}
\hline Eksogen & Endogen & $\begin{array}{c}\text { Original } \\
\text { Sample (O) }\end{array}$ & $\begin{array}{c}\text { Standard } \\
\text { Error } \\
(\text { STERR) }\end{array}$ & $\begin{array}{c}\text { T Statistics } \\
(\mid \mathbf{O} / \text { STERR|) }\end{array}$ & Keterangan \\
\hline \hline EE & EI & 0,273428 & 0,13532 & 2,020602 & Diterima \\
\hline EE & EM & 0,486164 & 0,122374 & 3,972756 & Diterima \\
\hline EM & EI & 0,432142 & 0,11834 & 3,651692 & Diterima \\
\hline
\end{tabular}




\section{Pengaruh Entrepreneurship Education terhadap Entrepreneurial Intention}

Hasil penelitian menunjukkan bahwa T-statistics pada pengaruh entrepreneurship education terhadap entrepreneurial intention menunjukkan angka 2,020602. Dengan demikian hipotesis 1 yang menyatakan bahwa Entrepreneurship Education memiliki pengaruh terhadap Entrepreneurial Intention diterima, berarti pendidikan kewirausahaan pada mahasiswa perguruan tinggi swasta di Surabaya memiliki berpengaruh terhadap entrepreneurial intention. Hal tersebut didukung dengan penelitian yang dilakukan oleh Gerba (2012) dalam penelitiannya menunjukkan bahwa pendidikan kewirausahaan memiliki pengaruh terhadap niat kewirausahaan. Hal ini terlihat dari hasil penelitian yang memperlihatkan bahwa mahasiswa yang telah menjalani pendidikan kewirausahaan yang secara terstruktur, dimana pendidikan merupakan penjabaran dari rangkaian belajar mengajar dalam sebuah perguruan tinggi cenderung memiliki niat kewirausahaan yang lebih baik dibandingkan siswa yang mengambil pembelajaran singkat meskipun bertema Kewirausahaan.

\section{Pengaruh Entrepreneurship Education terhadap Entrepreneurial Motivation}

Hasil penelitian menunjukkan bahwa T-statistics pada pengaruh entrepreneurship education terhadap entrepreneurship motivation menunjukkan angka 3,972756. Dengan demikian hipotesis 2 yang menyatakan bahwa Entrepreneurship Education memiliki pengaruh terhadap Entrepreneurship Motivation diterima. Hal tersebut didukung dengan hasil penelitian dari Oosterbeek, Praag, \& Ijsselstein (2010) mengungkapkan bahwa pendidikan kewirausahaan memiliki pengaruh terhadap motivasi kewirausahaan. Hal ini disebabkan dalam pendidikan kewirausahaan diterapkan berbagai aktivitas yang membangkitkan motivasi siswa dalam berwirausaha, sehingga setelah mendapatkan pendidikan siswa menmiliki motivasi yang meingkat dalam melakukan kegiatan kewirausahaan. Dengan demikian dapat dikatakan bahwa semakin luas pendidikan kewirausahaan yang diperoleh maka semakin tinggi pula motivasi yang dimiliki oleh siswa.

\section{Pengaruh Entrepreneurial Motivation terhadap Entrepreneurial Intention}

Hasil penelitian menunjukkan bahwa T-statistics pada pengaruh entrepreneurship motivation terhadap entrepreneurial intention menunjukkan angka 3,651692. Dengan demikian hipotesis 3 yang menyatakan bahwa Entrepreneurial Motivation memiliki pengaruh terhadap Entrepreneurial Intention diterima. Hal ini sebagaimana penelitian yang dilakukan oleh KimSoon, Ahmad, \& Ibrahim (2014), yang mana dari hasil penelitiannya mengungkapkan bahwa kekuatan motivasi mahasiswa tekhusus dalam hal memilih kewirausahaan sebagai pilihan karir memiliki hubungan berkaitan erat dengan niat kewirausahaan. Dengan demikian dapat dikatakan bahwa semakin 
tinggi motivasi kewirausahaan yang dimiliki maka semakin tinggi pula niat yang dimiliki oleh siswa.

\section{Pengaruh Entrepreneurial Motivation dalam Memediasi Entrepreneurship Education terhadap Entrepreneurial Intention}

Pada pengujian hipotesis ini dilakukan dengan pengujian indirect effect. Pengujian indirect effect dilakukan dengan tujuan untuk menguji ada tidaknya pengaruh secara tidak langsung variabel bebas terhadap variabel terikat melalui variabel interveningnya. Kriteria pengujian menyatakan bahwa apabila T-statistics $\geq$ T-tabel (1.645) maka dinyatakan terdapat pengaruh signifikan secara tidak langsung variabel eksogen terhadap variabel endogen melalui variabel interveningnya. Hasil pengujian indirect effect dapat dilihat melalui ringkasan dalam tabel 8 berikut.

Tabel 8. Indirect Effect

\begin{tabular}{lllccc}
\hline Eksogen & Endogen & Intervening & $\begin{array}{c}\text { Indirect } \\
\text { Coefficient }\end{array}$ & SE & $\begin{array}{c}\text { T } \\
\text { Statistics }\end{array}$ \\
\hline \hline $\mathrm{EE}$ & $\mathrm{EI}$ & $\mathrm{EM}$ & 0.01601 & 0.067 & 0.240 \\
\hline
\end{tabular}

Berdasarkan pengujian yang tertera dalam tabel 9 dapat diketahui bahwa pengaruh entrepreneurship education terhadap entrepreneurial intention melalui entrepreneurial motivation diperoleh nilai $\mathrm{T}$ statistics sebesar 0.240. Hasil pengujian tersebut menunjukkan bahwa nilai $\mathrm{T}$ statistics $<1.645$. Hal ini menunjukkan bahwa tidak terdapat pengaruh signifikan entrepreneurship education terhadap entrepreneurship intention melalui entrepreneurship motivation. Oleh karena itu entrepreneurship motivation dinyatakan tidak mampu memediasi pengaruh entrepreneurship education terhadap entrepreneurship intention.

Konversi diagram jalur dalam model pengukuran dimaksudkan untuk mengetahui pengaruh secara langsung maupun tidak langsung. Adapun efek model secara langsung maupun secara tidak langsung sebagaimana disajikan dalam tabel 9 berikut.

Tabel 9. Total Effect

\begin{tabular}{llcccc}
\hline Eksogen & Endogen & Intervening & $\begin{array}{c}\text { Direct } \\
\text { Coefficient }\end{array}$ & $\begin{array}{c}\text { Indirect } \\
\text { Coefficient }\end{array}$ & Total \\
\hline \hline EE & EI & EM & 0,273428 & & 0,273428 \\
\hline EE & EI & & 0,486164 & 0,016013769 & 0,502178 \\
\hline EM & EI & & 0,432142 & & 0,432142 \\
\hline
\end{tabular}


Berdasarkan tabel 9 dapat diketahui bahwa model pengukuran yang terbentuk adalah sebagai berikut.

$\mathrm{EI}=0,273428 \mathrm{EE}$

Dari persamaan 3 dapat diinformasikan bahwa Koefisien direct effect EE terhadap EI sebesar 0,273428 menyatakan bahwa EE berpengaruh positif dan signifikan terhadap EI. Hal ini berarti semakin tinggi EE maka cenderung dapat meningkatkan EI.

$$
\mathrm{PeEI}=0,486164 \mathrm{EE}+0,432142 \mathrm{EM} \text {. }
$$

Dari persamaan 4 dapat diinformasikan bahwa (1) Koefisien direct effect EE terhadap EI sebesar 0,486164 menyatakan bahwa EE berpengaruh positif dan signifikan terhadap EI. Hal ini berarti semakin tinggi EE maka cenderung dapat meningkatkan EI. (2) Koefisien direct effect EM terhadap EI sebesar 0,432142 menyatakan bahwa EM berpengaruh positif dan signifikan terhadap EI. Hal ini berarti semakin tinggi EM maka cenderung dapat meningkatkan EI. (3) Koefisien direct effect EE terhadap EI melalui EM sebesar 0,016013769 menyatakan bahwa EE tidak memiliki pengaruh positif dan signifikan terhadap EI melalui EM. Hal ini berarti semakin tinggi EM yang disebabkan meningkatnya EE maka cenderung dapat meningkatkan EI. Namun peningkatan secara tidak langsung ini tidak signifikan.

Variabel eksogen yang memiliki pengaruh dominan terhadap variabel endogen dapat diketahui melalui total efek yang paling besar. Hasil analisis menginformasikan variabel yang memiliki total efek terbesar terhadap adalah EI adalah EE dengan total efek sebesar 0,502178. Dengan demikian EE memiliki pengaruh yang paling dominan terhadap EI.

\section{KESIMPULAN}

Hasil penelitian menunjukkan bahwa T-statistics pada pengaruh entrepreneurship education terhadap entrepreneurial intention menunjukkan angka 2,020602. Hal ini berarti entrepreneurship education berpengaruh signifikan terhadap entrepreneurial intention. Sementara itu, hasil penelitian menunjukkan bahwa T-statistics pada pengaruh entrepreneurship education terhadap entrepreneurial motivation menunjukkan angka 3,972756. Hasil penelitian lainnya menunjukkan bahwa T-statistics pada pengaruh entrepreneurial motivation terhadap entrepreneurship intention menunjukkan angka 3,651692. Kemudian, dari hasil penelitian menunjukkan bahwa pengaruh entrepreneurial education terhadap entrepreneurial intention melalui entrepreneurship motivation diperoleh nilai $\mathrm{T}$ statistics sebesar 0.240. Hal ini menunjukkan bahwa tidak terdapat pengaruh signifikan entrepreneurship education terhadap entrepreneurial intention melalui entrepreneurial motivation. Oleh karena itu entrepreneurial motivation dinyatakan tidak mampu memediasi pengaruh entrepreneurship education terhadap entrepreneurial intention. 
Pada hasil penelitian menunjukkan bahwa dengan adanya pendidikan kewirausahaan akan menumbuhkan motivasi berwirausaha, namun bukan niat berwirausaha. Hal ini hendaknya menjadi perhatian yang lebih bagi pengajar mata kuliah kewirausahaan, yang mana dalam prakteknya memiliki peran yang cukup besar. Selain itu, penelitian ini dapat menjadi referensi bagi penelitian selanjutnya dengan topik yang sama serta disarankan untuk menambahkan variabel lain karena dimungkinkan ada variabel lain selain entrepreneurship education dan entrepreneurship motivation yang mungkin berpengaruh terhadap entrepreneurship intention. Hal ini dikarenakan nilai $\mathrm{R}$ Square menunjukkan adanya variabel lain yang tidak ikut diteliti yang dapat mempengaruhi entrepreneurship intention.

\section{REFERENSI}

Bae, T. J., Qian, S., Miao, C., \& Fiet, J. O. (2014). The Relationship Between Entrepreneurship Education and Entrepreneurial Intentions: A MetaAnalytic Review. Entrepreneurship Theory And Practice 1042-2587.

Dogan, E. (2015). The Effect Of Entrepreneurship Education On Entrepreneurial Intentions Of University Students In Turkey. Ekonometri ve statistik Sayl:23, 79-93.

Fereidouni, H. G., Masron, T. A., Nikbin, D., \& Amiri, R. E. (2010). Consequences Of External Environment On Entrepreneurial Motivation In Iran. Asian Academy of Management Journal Vol. 15, No. 2,July, 175-196.

Gerba, D. T. (2012). Impact of entrepreneurship education on entrepreneurial intentions of business and engineering students in Ethiopia. African Journal of Economic and Management Studies Vol. 3 No. 2, 258-277.

Hardjanti, R. (2012, Desember 01). Antrean Pengangguran D3 \& S1 Makin Panjang. Dipetik Maret 18, 2017, dari okezone.com: http://news.okezone.com/read/2012/12/01/373/725951/antreanpengangguran-d3-s1-makin-panjang

Himawan, A. (2016, Mei 09). Jumlah Pengusaha di Indonesia Baru 1,5 Persen dari Total Penduduk. Dipetik Maret 18, 2017, dari Suara: http://www.suara.com/bisnis/2016/05/09/133306/jumlah-pengusaha-diindonesia-baru-15-persen-dari-total-penduduk

Hussain, A., \& Norashidah. (2015). Impact of Entrepreneurial Education on Entrepreneurial Intentions of Pakistani Students. Journal of Entrepreneurship and Business Innovation ISSN 2332-8851 Vol. 2, No. 1.

ILO. (2015). Tren ketenagakerjaan dan sosial di Indonesia 2014 - 2015: Memperkuat daya saing dan produktivitas melalui pekerjaan layak. International Labour Organization. 
Julianto, P. A. (2016, Desember 08). Jumlah Wirausaha Baru di Indonesia Kalah dari Malaysia dan Singapura. Dipetik Maret 18, 2017, dari kompas.com: http://bisniskeuangan.kompas.com/read/2016/12/08/064604126/jumlah.wira usaha.baru.di.indonesia.kalah.dari.malaysia.dan.singapura

Khuong, M. N., \& An, N. H. (2016). The Factors Affecting Entrepreneurial Intention of the Students of Vietnam National University - A Mediation Analysis of Perception toward Entrepreneurship. Journal of Economics, Business and Management, Vol. 4, No. 2, February, 104-111.

Kim-Soon, N., Ahmad, A. R., \& Ibrahim, N. N. (2014). Entrepreneurial Motivation and Entrepreneurship Career Intention: Case at a Malaysian Public University. Crafting Global Competitive Economies: 2020 Vision Strategic Planning \& Smart Implementation, 1001-1011.

Kompasiana. 2013. 10 kota terbesar di Indonesia, Valid. Dipetik Maret 30, 2017. http://www.kompasiana.com/tholo/10-kota-terbesar-di-indonesiavalid_552047a9813311f77319f72b

Kreiser, P. M., \& Davis, J. (2010). Entrepreneurial Orientation and Firm Performance: The Unique Impact of Innovativeness, Proactiveness, and Risk-taking. Journal of Small Business and Entrepreneurship 23, no. 1, 3951.

Kumar, A., Poornima, Abraham, M., \& Jayashree. (2003). Enrepreneurship Development. New Delhi: New Age International.

Kyro, P. (2015). Handbook of Entrepreneurship and sustainable Development Research. Cheltenham, UK, USA: Edward Elgar.

Lekoko, Rankhumise, \& Ras. (2012). The effectiveness of entrepreneurship education: What matters most? African Journal of Business Management Vol. 6(51), 26 December, 12023-12033.

Mat, S. C., Maat, S. M., \& Mohd, N. (2015 ). Identifying Factors that Affecting the Entrepreneurial Intention among Engineering Technology Students. Procedia - Social and Behavioral Sciences 211, 1016 - 1022.

Mitchell. (2003). African Entrepreneurs: An Analysis of their Motivation for Starting their Own Business. SAJEMS NS 6 (2003) No 4.

Morris, M. H., \& Liguori, E. (2016). Annals Of Entrepreneurship Education and Pedagogy. Edward Elgar: Cheltenham, UK, USA.

Nanda, T. (2013, Desember 26). Migrasi Menyebabkan Kepadatan Penduduk di Kota Surabaya. Dipetik Maret 10, 2016, dari Kompasiana: http://www.kompasiana.com/tria.ananda/migrasi-menyebabkan-kepadatanpenduduk-di-kota-surabaya_552c1ea26ea834c65b8b45cc 
Oosterbeek, H., Praag, M. v., \& Ijsselstein, A. (2010). The impact of entrepreneurship education on entrepreneurship skills and motivation. European Economic Review 54, 442-454.

Sabandar, S. (2016, Maret 08). Minat Wirausaha di Indonesia Sangat Rendah. Dipetik Maret 18, 2017, dari tempo.co: https://m.tempo.co/read/news/2016/03/08/087751831/minat-wirausaha-diindonesia-sangat-rendah

Sloka, B., Kantane, I., Avotins, V., \& Jermolajeva, E. (2014). Analysis Of Entrepreneur's Motivation To Start Business (Comparative Studies In Latvia In Comparison With Canada, Usa, Mexico). European Integration Studies ISSN 1822-8402, 152-158.

Solesvik, M. Z. (2013). Entrepreneurial Motivations and Intentions: Investigating the Role of Education Major. Education+Training, Vol. 55, No. 3, 253-271.

Somby, H. M., \& Johansen, V. (2016). Entrepreneurship education: motivation and effort for pupils with special needs in Norwegian compulsory school. European Journal of Special Needs Education ISSN: 1469-591X.

Stephan, U., Hart, M., \& Drews, C.-C. (2015). Understanding Motivations for Entrepreneurship A Review of Recent Research Evidence. Enterprise Research Centre.

Tsordia, C., \& Papadimitriou, D. (2015). The Role of Theory of Planned Behavior on Entrepreneurial Intention of Greek Business Students. International Journal of Synergy and Research Vol. 4, No. 1, 23-37.

Venesaar, U., Kolbre, E., \& Piliste, T. (2006). Students' Attitudes and Intentions toward Entrepreneurship at Tallinn University of Technology. Research Gate. 